\title{
Complementizer selection and the properties of complement clauses in German ${ }^{1}$
}

\author{
Angelika Wöllstein
}

\begin{abstract}
Complement clauses in German can have a lexical complementizer when they are finite, but they must not have one when they are non-finite. I will argue that this distribution follows from the referential properties of the sentential complement. According to Grimshaw, only referential categories extend to functional projections. The status marker $z u$ in German infinitival complements can be shown to block reference. Thus, non-finite complement clauses with $z u$ do not project a left periphery and cannot host a complementizer.
\end{abstract}

\section{Riddle}

Finite complement clauses with verb-end structure must be introduced by a lexical complementizer in German, see $(1 \mathrm{a})^{2}$. Non-finite complement clauses in German must not have a complementizer ${ }^{3}$, see (1b). Non-finite clauses can be introduced with a complementizer if they are adjuncts, see (1c).
a. $\quad$..., *(dass/ob) sie sich ergeben.
b. Sie werden aufgefordert, $\left({ }^{*} u m\right)$ sich zu ergeben.
c. Sie haben verhandelt, *(um/ohne/(an)statt) sich zu ergeben.

The distribution and properties of the data in (1) are summarized in (2). 
(2)

\begin{tabular}{|c|c|c|c|}
\hline \multirow{2}{*}{} & & \multicolumn{2}{|c|}{ presence of items } \\
\cline { 3 - 4 } & $\begin{array}{c}\text { syntactic function } \\
\text { complement }\end{array}$ & complementizer & $z u$ \\
\cline { 3 - 4 } & & + & - \\
\hline finite clauses & + & - & + \\
\hline non-finite clauses & + & + & + \\
\cline { 2 - 4 } & - & & \\
\hline
\end{tabular}

The data are well known, but to my knowledge the question has never been addressed just why a lexical complementizer must not appear in the left periphery of a non-finite complement clause.

The riddle is defined by the following questions: What prevents the presence of a lexical complementizer in the left periphery in non-finite complement clauses? ${ }^{4}$ Which role does the positioning of the complementizer play for the type of proposition? Which property does the finite verb and the complementizer share in the highest functional position?

I will not only answer this riddle but also try to propose a solution for a greater one to be picked up later. The hypotheses are:

- The co-occurrence of $z u$-marked verbal head and the complementizer leads to a contradiction.

- Finite complementation is the result of the projection of a referential syntagma.

- Non-finite complementation is the representation of a non-referential syntagma.

The paper is organized as follows. Section 2 presents the theoretical context, in which the phenomena will be explored. Grimshaws theory of properties for functional extension, the principle of visibility formulated by Brandt/Reis/Rosengren/Zimmermann (1992) (in the following: BRRZ) and Haider's (1993) projective theory will build the background of this investigation. In section 3, I will demonstrate that the three status in German are aspect markers. The aspectual properties of $z u$ as a prospective marker will be connected with the proposals of Wunderlich (1996) and Steinitz (1997) for the categorisation of lexical items. In section 4, I will argue that 
prospectivity - embedded in a concept of referentiality - has conceptual relevance. In section 5, the findings will be related to a syntactic representation. Section 6 deals with sentence mood of embedded clauses and unembedded infinitivals and thus delivers a new perspective on the properties of the left periphery.

The overall conclusion is drawn in section 7 .

\section{Origin}

\subsection{Context}

In the literature, the appearance of the complementizer is considered to be the reflex of the occurrence of the finite verb in the right edge, see BBRZ. Non-finite complement clauses are assumed to be sentential, incoherent, ${ }^{5}$ and therefore functionally extended projections if they are extraposed entirely, see Haider (1993), Sabel (1996). ${ }^{6}$

In Grimshaw (1991), it is assumed that extended projections always result from referential categories, while non-referential categories do not extend to functional projections. We will see, however, that clausal properties like incoherence cannot be made to follow from the availability of a functional projection even if finite clauses seem to suggest that this is possible.

In Wunderlich (1996) and Steinitz (1997), Grimshaw's idea has a parallel in some morphologically based assumptions about the referentiality of lexical categories. The impact of referentiality does indeed build up to a further argument for the contrast between the finite and the most superior non-finite verb in the right edge, and in this article I will focus on how to interweave the assumptions drawn from the lexical and those from the syntactic module. I will make use of the morpho-syntactic interface developed in Lohnstein/Wöllstein-Leisten (2001), where the non-finite verbal paradigm in German was considered to be the expression of aspect. It was particularly shown that the prospective aspect ( $z u$-marked non-finite verb, the so called $2^{\text {nd }}$ status) cannot receive an epistemic reading. I will show that this idea carries over to the referentiality of the lexical head category and ultimately to the functional extension in both finite and non-finite clauses, and I hope thus to achieve a better understanding of the correlations observed between the inflectional morphology and the phrasal context. 


\subsection{Theoretical assumptions}

The phenomenology of finite and non-finite complement clauses is embedded in the following theoretical assumptions from Grimshaw, Steinitz, Wunderlich, BRRZ and Haider:

Grimshaw's (1991) foundation for extended projection and the availability of functional (head) positions can be formulated as in (3): ${ }^{7}$

Extended Projection

Referential categories extend to functional projections.

Wunderlich (1996) and Steinitz (1997) assume that the category $V$ is referentially independent, as stated in (4).

Referential Independence

The referential argument of the lexical item $\mathrm{V}$ serves as the anchor of a situation. The task of functional categories is the syntactic linking of the referential argument.

In Haider's (1993) representational approach, the presence of phonetic items in a language is the basic requirement for functional positions and projection in general. The number of heads that occur within a syntactic chain are elements of the core grammar of a given language. Only the functional and lexical heads that are phonetically present in a specific language project the syntactic structure.

\section{Projective Grammar}

Overt functional and lexical heads and their morpho-syntactic features are relevant for the projection of a syntactic structure. In the absence of such indication, there is no further projection.

In German, for example, there is no evidence of a sentence-final functional head $\mathrm{I}^{0}$; on the contrary, Höhle (1991) shows that there is in fact counterevidence for a $\mathrm{V}$ to I raising. ${ }^{8}$ Following this observation, the projection of a structure is a representation of a given chain. Where functional heads and their features are missing, no further projection proceeds. Consequently, in German we have a VP-internal subject position.

As an abstract functional position I take Haider's (1996) lable FP for the single functional projection above the VP, where $\mathrm{F}^{0}$ is accessible for the finite verbal head or the lexical complementizer. ${ }^{9}$ As a result, German provides the following sentence structure with a single functional shell. 
(6)

$$
\left[\mathrm{FP} \operatorname{SpecF}\left[\begin{array}{llll}
\mathrm{F}^{0} & \mathrm{~F}^{0}[\mathrm{vP} & \ldots & \mathrm{V}^{0}
\end{array}\right]\right]
$$

In BRRZ, the structure of main clauses and subordinate clauses is discussed. The dichotomy of the distribution of complementizers in $\mathrm{C}^{0}$ and the finite verb in the right edge on the one hand, and the finite verb in $\mathrm{C}^{0}$ in V-2 and V-1 sentences on the other hand is covered by the principle of visibility. Due to the principle of visibility, that is, that the highest maximal projection must be visible in its head position, the positioning of the complementizer follows. The principle can be formulated as in (7).

\section{Principle of visibility}

The highest maximal projection must be visible in its head position.

\subsection{Data}

To distinguish the data discussed here, I will give a short survey of the distribution of elements in the left periphery in complement clauses. The distribution in the left periphery in German given in the examples in (8) is summarized in (9).

a. Hans weiß, Maria kommt heute.

'Hans knows Maria is coming today.'

b'. Hans weiß, wer *kommt heute.

'Hans knows who is coming today.'

b'. Hans weiß, wer heute kommt. ${ }^{10}$

'Hans knows who is coming today.'

c. Hans weiß, (*heute) dass / ob Maria kommt.

'Hans knows that/whether Maria is coming.'

d. Sie wurden aufgefordert, sich wem zu ergeben.

'They were asked to surrender to somebody.'

d'. $\quad$ Sie wurden aufgefordert, *wem sich zu ergeben.' 
(9) Distribution in the left periphery

\section{Overview}

\begin{tabular}{|c|c|c|c|c|c|c|c|c|c|c|}
\hline \multirow{2}{*}{\multicolumn{2}{|c|}{$\begin{array}{c}\text { Comple- } \\
\text { ment } \\
\text { clause }\end{array}$}} & \multicolumn{9}{|c|}{ Position in the left periphery } \\
\hline & & \multirow{2}{*}{$\begin{array}{c}\text { Spec } \\
\text { F } \\
+\end{array}$} & \multirow{2}{*}{$\frac{\mathrm{F}^{0}}{+}$} & \multirow{2}{*}{$\begin{array}{c}\begin{array}{c}\text { Spec } \\
\text { F }\end{array} \\
+\end{array}$} & \multirow{2}{*}{$\begin{array}{c}\mathrm{F}^{0} \\
-\end{array}$} & \multirow{2}{*}{$\begin{array}{c}\text { SpecF } \\
-\end{array}$} & \multirow{2}{*}{$\begin{array}{l}\mathrm{F}^{0} \\
+\end{array}$} & \multirow{2}{*}{$\begin{array}{c}\text { SpecF } \\
\varnothing\end{array}$} & \multirow{2}{*}{$\begin{array}{l}\mathrm{F}^{0} \\
\varnothing\end{array}$} & \multirow{2}{*}{$\begin{array}{r}\text { FP } \\
+\end{array}$} \\
\hline 1 & finite & & & & & & & & & \\
\hline 2 & $\begin{array}{l}\text { non- } \\
\text { finite }\end{array}$ & $\varnothing$ & $\varnothing$ & $\varnothing$ & $\varnothing$ & $\varnothing$ & $\varnothing$ & - & - & - \\
\hline & & & \multicolumn{2}{|c|}{ B } & \multicolumn{2}{|c|}{$\mathrm{C}$} & \multicolumn{2}{|c|}{$\mathrm{D}$} & $\mathrm{E}$ \\
\hline
\end{tabular}

FP designates the unspecified highest functional projection. ' $\varnothing$ ' means that this is no possible distribution, ' + ' means to be occupied by a lexical item and '-' to be not occupied by a lexical item.

Based on the distribution of data, the following can be established:

(10) a. At least one position in the left periphery must be occupied in finite complement clauses, see $(8 \mathrm{a}-\mathrm{c})$ and $[1 \mathrm{~A}-\mathrm{C}] /[1 \mathrm{E}]$ vs. [1D] in the table in (9).

b. There is no overt element in the left periphery in non-finite complement clauses, see (8d) and $[2 \mathrm{D}] /[2 \mathrm{E}]$ in the table in (9).

Non-finite complements in German solely appear with $z u$-marked infinitive. Let us now turn to the grammatical properties of the infinitival forms (henceforth status).

\section{Status and Aspect}

In his groundbreaking work, Bech (1953) introduces a theory of status government pertaining to the relationship among the elements of the category $V$. Thereby, status theory can be understood as a parallel to case theory. 


\subsection{Status government}

Bech (1953) distinguishes between three types of status corresponding to three types of infinitival forms, and two stages, that is the supine and the participium. ${ }^{11}$

(11) The three status of the infinitive lieben ('love')

\begin{tabular}{l|l|l} 
Status & Supine & Participium \\
\hline 1. status & lieben & liebend (-e) \\
\hline 2. status & zu lieben & zu liebend (-e) \\
\hline 3. status & geliebt & geliebt (-e)
\end{tabular}

The three verbal status in German are divided into bare infinitive that designates the $1^{\text {st }}$ status $(12 \mathrm{a}), z u$ - $($ to $)$ infinitive designating the $2^{\text {nd }}$ status (12b), and the past participle designating the $3^{\text {rd }}$ status (12c). Every verb in a chain that is governed in Bech's sense by a superior verb is forced to occur in a specific status:
a. Modal verbs govern the $1^{\text {st }}$ status.
b. Main verbs govern the $2^{\text {nd }}$ status.
c. Auxiliaries govern the $3^{\text {rd }}$ status.

Diverging from Bech's theory of status government, we observe that more generally:

a. Main verbs do not occur with the $3^{\text {rd }}$ status; in ECM constructions main verbs occur with the $1^{\text {st }}$ status.

b. Auxiliaries may occure with all three status; in IPP constructions auxilliaries occur with $1^{\text {st }}$ status ${ }^{12}$ and in constructions with modal meaning they occur with the $2^{\text {nd }}$ status.

Evers (1975), Grewendorf (1987), Haider (1987), Jacobs (1990), Stechow \& Sternefeld (1988), Rosengren (1992) and others show that only the $2^{\text {nd }}$ status is allowed to be constructed incoherently, whereas the latter correlates with sentential properties. Coherence mirrors monosentential properties such as clause union and the formation of a verbal complex of the matrix verb and the governed verb(s), see Haider (1993). ${ }^{13}$ Only infinitival constructions with the $2^{\text {nd }}$ status alternate with finite complements introduced by the complementizer dass. 
Within the scope of this work, we are dealing with the properties of the supine as aspect marker with main focus on the syntax and semantics of German $z u$.

\subsection{Status as Aspect Marker}

Aspect in German cannot be expressed in the finite verbal paradigm, though, for example, lexical supplements like immer, dauernd or am + verb (-ing-form), or periphrasic forms of verb + werden / haben, sein are able to assign aspectuality (cf. Bartsch 1995). ${ }^{14}$

Wunderlich (1993) argues that a lexical category $V$ refers to a possible situation configuring the shape of time. ${ }^{15}$ Aspect shall be deemed to be the establishment of the situation structure, which can be expanded or selective, with or without termination, or the indication of the resultative state of a situation. The resultative state can be available or can be missing. Thereby aspect must be distinguished from tense in the way that tense marking is the integration of a situation type (illustrated in (15)) in time no matter whether the situation is past or not, or future or not. Contrary to Klein (2000), Lohnstein/Wöllstein-Leisten (2001) and Wurmbrandt (2001) argue that verbal status, that is to say the non-finite verbal paradigm, in German functions as aspect marker and not as a marker for tense.

In Wurmbrandt (2001), the $2^{\text {nd }}$ status characterizes the [IRR](ealis) aspect describing an event or situation that has not yet been realized during the reference time based on the event or situation defined by the matrix verb. Under this assumption, elements that cause a perfective context like the adverb gestern in combination with the $2^{\text {nd }}$ status lead to a contradiction with the [IRR] context, depending on the reference time of the matrix verb or further elements.

a. Erversucht, (*gestern) zu verreisen. / Er versuchte, gestern zu verreisen.

'He tries to go away.' / 'He tried to go away yesterday.'

b. Er bedauert, ('gestern) zu verreisen. / Er bedauerte, gestern zu verreisen.

'He regrets to go away.' / 'He regretted to go away yesterday.'

Lohnstein/Wöllstein-Leisten (2001) propose that all of the three status are linked with a type of aspectual interpretation, revealing that in German we 
do have aspect, but with infinitival forms only. The association of one of the three status with a verb is independent of the ontological category or the type of situation (accomplishments/achievements, activities, or states) described by the verb meaning.

(15) Type of situation and type of aspect

\begin{tabular}{l|l} 
Type of situation & Type of aspect \\
\hline continuous & durative ${ }^{16}$ \\
\hline intended & prospective \\
\hline terminated & perfective
\end{tabular}

With the commitment to an aspect, the speaker refers to his/her comprehension of the type of situation to be denoted by the verb. The following distinctions can be made:

(16) Status as aspect marker

\begin{tabular}{l|l|l} 
Status & Supine & Type of aspect \\
\hline 1. status & lieben & durative \\
\hline 2. status & zu lieben & prospective \\
\hline 3. status & geliebt & perfective
\end{tabular}

To duplicate the assignment of the aspects to the status, it is sufficient for the present to contrast the interpretation of the prospectivewith the perfective reading of the verbal aspect. ${ }^{17}$ The following examples in (17)-(23) illustrate the resulting readings of the corresponding aspect marker:

\subsubsection{Prospective vs. perfective readings with the $1^{\text {st }}$ status (supine)}

The examples in (17a-b) imply the reading in (17c):

(17) [prospective]
a. $\quad$ Fritz hat den Computer zu reparieren. [ $2^{\text {nd }}$ status, supine]
'Fritz has to repair the computer.'
b. Der Computer ist zu reparieren. [ $2^{\text {nd }}$ status, supine $]^{18}$
'The computer needs to be repaired.'
c. Der Computer ist derzeit noch nicht repariert.
'The computer has not been repaired at present.' 
The examples in (18a-b) imply the reading in (18c):

(18) [perfective]
a. Fritz hat den Computer repariert. [ $3^{\text {rd }}$ status, supine]
'Fritz has repaired the computer.'
b. Der Computer ist repariert. [ $3^{\text {rd }}$ status, supine]
'The computer is repaired.'
c. Der Computer ist zu diesem Zeitpunkt repariert.
'The computer has been repaired at that point in time.

3.2.2. Prospective versus perfective readings with the $2^{\text {nd }}$ status (participium)

The example in (19a) does not imply the reading in (19b):

(19) [prospective]

a. $\quad$ der zu reparierende Computer
$\left[2^{\text {nd }}\right.$ status, participium $]$
'the computer to be repaired'

b. *der reparierte Computer 'the repaired computer'

The example in (20a) does not imply the reading in (20b):

(20) [perfective]
a. der reparierte Computer
[ $3^{\text {rd }}$ status, participium]
'the repaired computer'
b. *der zu reparierende Computer

\subsubsection{Readings with adverbials}

Adverbials that indicate time spread as in drei Stunden 'within/in three hours' show opposite interpretations in combination with the $2^{\text {nd }}$ and $3^{\text {rd }}$ status. 
(21) Types of temporal reading and the state of interpretation

\begin{tabular}{c|c|c} 
Status & Temporal reading & State of interpretation \\
\hline 2. status & ingressive & preceeding state \\
\hline 3. status & egressive & succeeding state
\end{tabular}

The interpretation of the proposition in (22) is illustrated with an attributive construction:

(22) Fritz hat in drei Stunden den Computer zu reparieren.

'Fritz has to repair the computer within/in three hours.'

[ $2^{\text {nd }}$ status, supine]

a. $\quad$ der zu reparierende Computer (ingressive)

[ $2^{\text {nd }}$ status, supine $]$

'the computer to be repaired'

b. $\quad *$ der reparierte Computer (egressive and also eventive)

[ $3^{\text {rd }}$ status, supine]

'the repaired computer'

The interpretation of the proposition in (23) is illustrated with an attributive construction:

(23) Fritz hat in drei Stunden den Computer repariert.

'Fritz has repaired the computer within three hours.'

[ $3^{\text {rd }}$ status, supine]

'Fritz will have repaired the computer (with)in three hours.'

a. der reparierte Computer (egressive and also eventive)

'the repaired computer'

[ $3^{\text {rd }}$ status, supine $]$

b. $\quad$ *der zu reparierende Computer (ingressive)

$\left[2^{\text {nd }}\right.$ status, supine $]$

'the computer to be repaired'

We can thus conclude that the $2^{\text {nd }}$ status describes situations (events, stages and processes) that have not been initiated relative to the shape of time configurated by the governing verb; that is, it denotes the preceding state of a situation and only permits an ingressive reading. ${ }^{19}$ The $3^{\text {rd }}$ status describes an egressive reading, denoting the succeeding state of a situation, see (21). As a further reason why I consider status as an aspect marker which is independent from the category tense, compare the examples (17)-(23). The 
status-marked participia occur within attributive constructions; and these, since they are nominals, are tenseless.

The following scheme in (24) finally illustrates the range of validity of the aspect marker in the given examples. Their validity is measured by reference time, marked with the vertical bar, see Lohnstein/WöllsteinLeisten 2001.
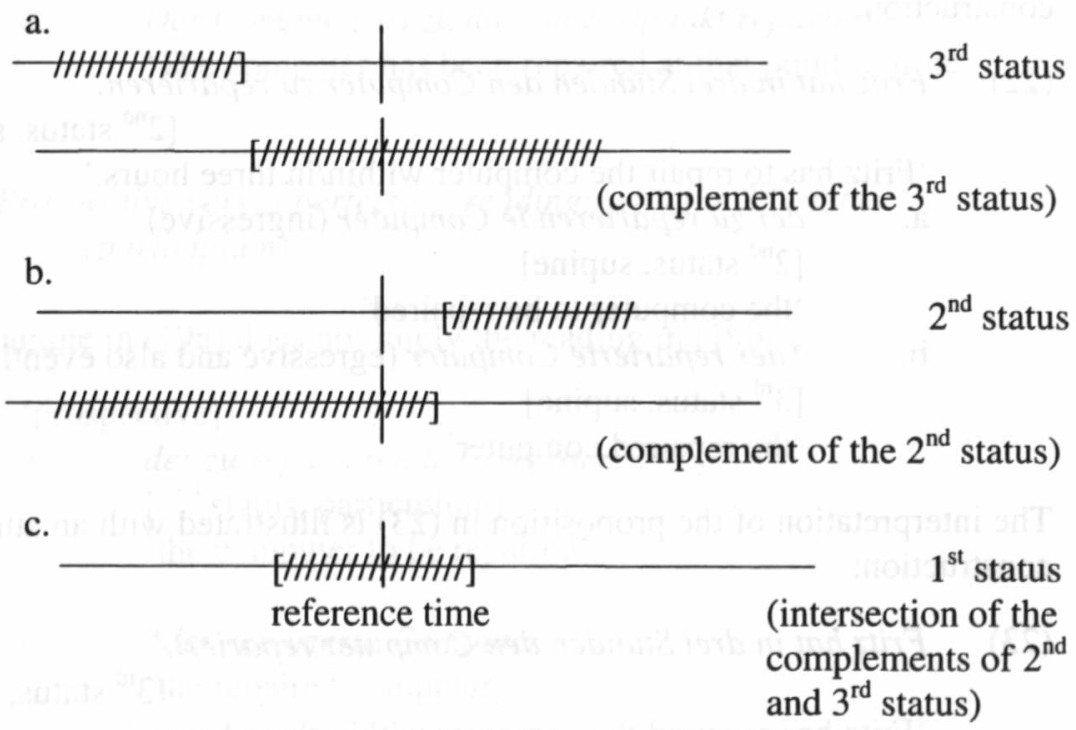

\section{Status and Referentiality}

Reference is the symbolic relationship between a linguistic expression and the concrete object or abstraction this expression represents. Since Donald Davidson's groundbreaking study The logical form of action sentence (1967), events have played a key role in the explanation of an increasing number of linguistic phenomena. The basic assumption of the Davidsonian paradigm is that events (or more general: 'situations'), like objects, are realworld entities. ${ }^{20}$ Most importantly, events are perceptible, countable, and can be located in time and space. Events, originally introduced as an additional argument position for only one class of verbs, were soon adopted for all verbs and in the meantime have been posited for every other lexical head (see, e.g., Higginbotham 2000, Parsons 2000).

With the extended categories $I$ and $C$ of the lexical head of the category $V$ as well as with the extended category $D$ of $N$, semantic fixing of the lin- 
guistic expression can be associated with a non-linguistic object or event. It is assumed that it is $I$ and/or $C$ respectively $F$ to which the referential argument of the verb is linked by the situation or event argument. ${ }^{21}$

Let us take a look at the close relation between reference, situation argument and the functional extension.

\subsection{Categorization of lexical items}

In accordance with the assumptions in section 3.2 , a situation argument is inherent in the lexical category $V$. Wunderlich (1996) and Steinitz (1997) assume that the referential argument of a verb serves as the anchor of situation indicated by $V$ within the non-linguistic context. The task of the functional categories is the syntactic linking of the referential argument. In other words, referential independence results from syntactic linking of the referential argument. This status of independence at least derives for the categories $V$ and $N$. The categorization of lexical items according to Wunderlich is illustrated in (25):22

(25) Categorization of lexical items

\begin{tabular}{l|l|l} 
Lexical category & referentially dependent & articulated/relational ${ }^{23}$ \\
\hline$N$ & $-I(e)$ & - \\
\hline$V$ & $-I(e)$ & + \\
\hline$A$ & + & - \\
\hline$P$ & + & +
\end{tabular}

With respect to the lexical category $V$, the following properties are valid:

(26) a. $\quad V$ is referentially independent. The default value of $V$ is to possess a referential argument $(\boldsymbol{e})$ marked in column $2 .^{24}$

b. $\quad V$ is functionally extendable.

Lets take a look at the idea that under certain conditions a proposition denoted by $V$ can refer to a possible situation depending on the realization of a specific morpho-phonological marker. One of these sorts of markers is the aspect marker. 


\subsection{Background of speech}

Aspect as opposed to tense reflects the background of speech which functions as the basis for the interpretation of the inventory of what can be known or what constitutes an expected situation. Thereby, one can distinguish between two ontologically given backgrounds that are anchored in the intentional system, the epistemic background and the factual (nonepistemic) background. ${ }^{25}$

The epistemic background reflects what belongs to the knowledge basis. Accordingly, the set of propositions based on this background is the index of what is known and what is $t$ (rue). The relation between the intensional and the extensional system (word and world) ${ }^{26}$ which is established here can be described as word to world accommodation.

The factual background reflects what is the actual state or what will be the fact in further progression due to the situation described by a proposition. If in further progression a situation described in a proposition occurs, it follows that the proposition will receive the truth value $t$ (rue). In this case, the relation between the intensional and the extensional system (world and word) can be described as world to word accommodation.

Now the types of aspects can be assigned a particular background of speech:

(27) Status, types of aspect and the background of speech

\begin{tabular}{|c|c|c|c|}
\hline Status & Types of aspect & $\begin{array}{r}\text { Type of accommoda- } \\
\text { tion }\end{array}$ & Background of speech \\
\hline 1. status & durative & & current $^{27}$ \\
\hline 2. status & prospective & world to word & non-epistemic \\
\hline 3. status & perfective & word to world & epistemic \\
\hline
\end{tabular}

With the aspect prospective we can associate a world to word accommodation; with the aspect perfective we can associate a word to world accommodation.

Referring to a situation (e.g., word to world) - see the argumentation above - the category $V$ is referential and can be functionally extended. Furthermore, if a proposition encloses a functionally extended $V$-projection, the proposition becomes truth-compliant. 


\subsection{Referentiality of propositions}

There are several possibilities for testing the referentiality of propositions. If a proposition is referential, parts of the proposition can be asked for or can be resumed by a pronoun. General questions like What has happened? are possible.

Due to the inflection-marker, propositions with a finite verb are functional extensions of the lexical head $V$. Hence finite complement clauses should be referential. However, it will be shown that certain propositions denoted by $V$ do not refer to possible situations when a specific morphophonological marker is realized. Under this condition of feature realization, the category $V$ is not referential and can not be functionally extended. To show whether a proposition is referential or not, let us test what happens in finite and non-finite complement clauses.

a. Maria hat behauptet, dass sie den Hund geschlagen hat. Ich bedauere es/das.

'Maria claims that she has beaten the dog. I am sorry for that.'

b. Ich bedauere, dass sie behauptet hat, dass sie den Hund geschlagen hat.

'I am sorry that she claims that she has beaten the dog.'

c. Ich bedauere, dass sie den Hund geschlagen hat.

'I am sorry that she has beaten the dog.'

What can be regretted is accessible with the reading in $(28 b, c)$. Only finite complement clauses can be resumed by a pronoun, see (28a). Concerning non-finite complement clauses this is not possible, see (29).

a. Maria hat behauptet, den Hund geschlagen zu haben.

Ich bedauere es/das.

'Maria claims, to have beaten the dog. I am sorry for that.'

b. Ich bedauere, dass sie behauptet hat, den Hund geschlagen zu haben.

'I regret that she claims to have beaten the dog.'

What can be claimed is accessible with the reading in (29b). A reading like in $(28 \mathrm{c})$ is not accessible. 
Referential expressions, like the finite complement clause but not the nonfinite complement clause with $z u$, are accessible for a resumption by a pronoun. The following generalization holds.

\section{Generalization 1}

$2^{\text {nd }}$ status blocks referentiality

This observation can be linked with the fact that the $2^{\text {nd }}$ status can be interpreted as prospective. The ingressive reading that is available for the $2^{\text {nd }}$ status can always only map the preceding state with respect to a situation that is expressed by the $2^{\text {nd }}$ status. The expressed situation itself is not available for an interpretation on an epistemic basis; the designated situation is not yet part of the things that are known and therefore is not available for a pronominal resumption. So the choice of the $2^{\text {nd }}$ status forces a world to word accommodation.

In combination with assumptions of Wunderlich (1996) and Steinitz (1997), we can argue that only referential expressions can be extended functionally, but not non-referential expressions. That is, the lexical category $V$ is referentially independent per default but can nevertheless lose its referentiality under certain conditions. This leads to the second generalization:

\section{Generalization 2}

\section{Lack of referentiality blocks the functional extension of $\mathrm{V}$}

If this is true and with the $1^{\text {st }}$ and $3^{\text {rd }}$ status being interpreted as actual and perfective on an epistemic background and therefore belonging to the things that are known, the choice of these status forces a word to world accomodation. Accordingly, these situations can be interpreted referentially like the situations that are designated by the inflectionally marked $V$ category.

\subsection{Status as marker for (non-)referentiality}

Referentiality versus non-referentiality is encoded in different positions. In general, referentiality is marked at the right-peripheral position of the $V$ stem. 
(30) Distribution of morpho-phonological marker of Bech's supine

\begin{tabular}{l|r|c|l} 
Status & $\begin{array}{r}\text { marker [-ref] } \\
\text { left-peripheral }\end{array}$ & V-stem & $\begin{array}{l}\text { marker [+ref] } \\
\text { right-peripheral }\end{array}$ \\
\hline 1. status & $\varnothing$ & $\mathrm{V}$ & $e n /{ }^{*} t$ \\
\hline 2. status & $z u$ & $\mathrm{~V}$ & $e n /{ }^{*} t$ \\
\hline 3. status & $*_{z u}$ & $\mathrm{~V}$ & $e n / t^{28}$
\end{tabular}

Referentiality is the default value of $V$ and is inherent in the category which is what Wunderlich (1996) and Steinitz (1997) call referential independence. With $z u$, the infinitival morphology in the left-peripheral position blocks the referentiality of the verbal category; right-peripheral markers in general refer to referential objects and situations in the finite paradigm (e.g., object reference with person and number as well as situation reference) and solely situation reference in the $1^{\text {st }}$ and $3^{\text {rd }}$ status in the non-finite paradigm (e.g., epistemically interpretable). The left-peripheral morphophonological marker prevents the syntagma from establishing any referential relation (neither object nor situation).

Again, within the verbal paradigm the inflectional marker takes on the task of referential selection on the individual or object level. Within the infinitival verbal paradigm there is no concrete object reference; the referential selection, however, is equally located at the right-peripheral position of the $V$-stem marking the situational level. ${ }^{29}$ Only the left-peripheral morphology marks a non-referential situational level. The distribution of the feature $[ \pm$ ref $]$ can be illustrated as follows.

The referentiality of the verbal paradigm

situational level

individual/object level

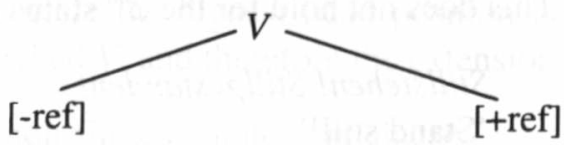

$z u$

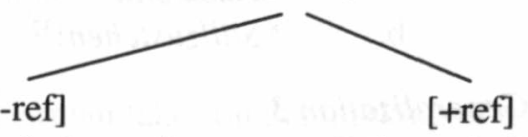

non-finite verbal paradigm

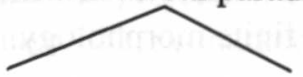

finite verbal paradigm 
The right-peripheral infinitival marker en/t does not interact with the feature [+ref]. However, just like the left-peripheral marker, $z u$ marks the lack of referentiality [-ref].

To conclude, referentiality forms a distributional class. Thereby it is irrelevant whether bound finite verbal marker or the referential infinitival marker, $e n / t^{30}$ but not $z u$ is right-peripherally marked. ${ }^{31}$

On the situational level (functionally extended projection) referentiality is indicated and functional extension is not blocked. The verbal syntagma on this level provides a situation argument. Non-referentiality is leftperipherally marked with $z u$. Referentiality on the object level (morphological inflection) right-peripherally marks the identification of the intended reference with person, tense and verbal mood.

\section{Syntactic structure}

I consider the feature [+ref] as a concept of referentiality of a lexical as well as a projecting category. Let us now take a look towards the consequences for syntactic projection.

\subsection{Functional extension}

The following question arises: If prospectivity blocks referentiality, does non-referentiality block functional extension of (possible referential) lexical heads? If this were the case, the following could be predicted: In an extended higher projection, the $1^{\text {st }}$ and the $3^{\text {rd }}$ status can occur independently as in (32a). This does not hold for the $2^{\text {nd }}$ status as illustrated in (32b).
a. Stillstehen! Stillgestanden!
'Stand still!'
b. *Stillzustehen! ${ }^{32}$

\section{Generalization 3}

Functional extension is available even without a referentially marked object level, i.e., even without finite morphology.

Within Haiders (1993) 'projective theory', features of lexical or functional categories always determine projections. Where features are not specified, there is no further extension or projection. In accordance with the current 
discussion, I suggest the following syntactic structure of finite and independent non-finite main clauses, where the projecting item $\mathrm{V}^{0}$ has the property of being referential.

(33) functionally extended projection of a finite and free non-

finite clause

$\left[\mathrm{FP}(\mathrm{XP}) \mathrm{F}^{0} \ldots\left[\mathrm{VP} \mathrm{V}^{0}\right]\right]$

\subsection{Visibility of the highest maximal projection}

The syntactic structure of a finite complement clause is the projection of a referential category $V$, where the finiteness morphology serves as the referential anchoring via a set of markers for person, tense, and verbal mood. The $F$-head functions as the functional extension of the referential category $V$, whereby the occupation of this head through the complementizer meets the visibility condition of BRRZ. The highest maximal projection must be visible in its head position. Hence the complementizer dass makes visible the most superior head position in finite complement clauses.

(34) functionally extended projection of a finite complement

clause $\left[\mathrm{FP}(\mathrm{XP}) \mathrm{F}^{0} \ldots\left[\mathrm{vP} \mathrm{V}^{0}\right]\right]$

There is no difference in the projection between finite, free non-finite and embedded finite clauses. In non-finite complement clauses, it is the verbal head itself that makes the highest projection visible. There is no functional extension because the verbal head constitutes a non-referential syntagma. The condition of making visible the highest head position is already fulfilled by the prospective-marked $V$, and therefore the extension is blocked.

$$
\begin{aligned}
& \text { representation of a non-finite complement clause } \\
& {\left[\mathrm{vP} \ldots \mathrm{V}^{0}\right]^{33}}
\end{aligned}
$$

The articulated complementizer dass in German takes on the marking of the head position in the highest maximal projection of a referential syntagma within a finite complement clause; the $z u$-marked infinitive takes on the marking of the highest head of a non-referential syntagma for a non-finite complement clause. Accordingly, dass and $z u$ contrast in the quality of the type of complementation they determine, depending on whether the com- 
plement clause is referential or not. The hypotheses given at the beginning are confirmed.

The concept of referentiality has been shown to be of just the right level of abstraction in order to deal with the properties of both lexical categories and clauses. In the remainder of this article, I will attempt to extend the discussion to cover the correlation of sentence mood and complementation within the left periphery: we need to ask which properties of non-finite forms in German licence the properties of a clause even though there is no finite verb.

\section{Greater Riddle}

As it is undoubted that sentence mood is anchored within the left periphery, and since the left periphery was argued to be the domain of the functionally extended VP, what are the licencing conditions for the extension of nonfinite verbs?

\subsection{Sentence Mood}

In finite complement clauses, a subset of sentence moods is available: declarative, wh-interrogative, but no imperative (imp). Non-finite complement clauses are unspecified in relation to sentence mood, whereby unembedded bare infinitives (inf) and the past participle (ppart) can function as a surrogate for [+imp]. ${ }^{34}$
a. Herkommen! / Hergekommen!
'Come here!'
b. *Ich befehle dir herkommen / hergekommen.
'I order you to come here.'

In sentential infinitivals containing wh-phrases, see (37a), the clause type is also unspecified. Only if the wh-phrase or the wh-containing phrase appears in topic position of the embedding verb, see $(37 \mathrm{~b}, \mathrm{c})$, the clause type [+wh] is assigned.

$$
\begin{aligned}
& \text { a. } \quad \text { Du hast bedauert, [wen zu treffen]. } \\
& \text { *'You have regretted whom to meet.' } \\
& \text { 'You have regretted to meet whom.' }
\end{aligned}
$$


$\begin{array}{lll}\text { b. } & \text { [Wen zu treffen] hast du bedauert? } & \text { [+wh] } \\ \text { c. } & \text { Wen } n_{i} \text { hast du bedauert, [ } t_{i} \text { zu treffen]? } & \text { [+wh] }\end{array}$

The wh-phrase in situ, see (37a), has two interpretations: a) an indefinite interpretation if unstressed and b) an echo-wh-interpretation if stressed. In (37b) and (37c), the clause type of the matrix-clause is [+wh]; that is, only in $(37 b, c)$ we have request character, see Eden (this volume).

As mentioned above, the absence of the $z u$-marker (situational level marked with [+ref]) within the infinitival morphology correlates with the availability of sentence mood. ${ }^{35}$ The infinitivals in the $1^{\text {st }}$ and $3^{\text {rd }}$ status can be used as surrogate forms of the sentence mood [+imp]. Also, in subjectless interrogatives the wh-infinitivals appear to have sentence mood, and, according to the preceding discussion, they are referential syntagmas with functional extension. ${ }^{36}$
a. Womit noch rechnen können $?^{37}$
'What can we still expect?'
b. Was noch glauben?
'What can we still believe?'

The correlation between the clausal properties referentiality and sentence mood is illustrated in the table (39). From the presence or absence of the marker $z u$ follows the distribution of the features [ref] and [sm] at the situational level of the clause.

The presence / absence of $z u$

\begin{tabular}{c|c}
$z u$-marker present & $z u$-marker absent \\
\hline$[$-ref $]$ & {$[+$ ref $]$} \\
\hline$[-\mathrm{sm}]$ & {$[+\mathrm{sm}]$}
\end{tabular}

\section{Generalization 4}

In the non-finite paradigm, referentiality correlates with the presence of sentence mood $(\mathrm{sm})$.

It should not come as a surprise that non-finite clauses that are able to appear without an embedding context are capable of expressing sentence mood: Our discussion has shown that the morphological expression of the $1^{\text {st }}$ and $3^{\text {rd }}$ status functions as an aspectual marker indicating referentiality. This is why these constructions can be functionally extended and therefore 
show a left periphery, i.e., the clausal position for the expression of sentence mood. It also follows that the structure of main and embedded clauses cannot be identical. This is exactly what Reis (2002) has been arguing for similar reasons. However, main clauses and embedded clauses can have a uniform structure if the expressed proposition is referential. This is the case in all V-2 and such V-end clauses that have a lexical complementizer. A different structure is found only in embedded clauses that are both nonfinite and complements.

\subsection{Complementation}

The $2^{\text {nd }}$ status and finiteness, as has just been said, correlate with the type of sentential complementation; finite complementation and non-finite complementation contrast in the following markers:

(40)

\begin{tabular}{l|l}
{$[+$ finite $]$} & {$[+\mathrm{ref}][+\mathrm{sm}]$} \\
\hline$[$-finite $]$ & {$[-\mathrm{ref}][-\mathrm{sm}]$}
\end{tabular}

\section{Generalization 5}

$2^{\text {nd }}$ status and finiteness correlate with the possibility of complementation. Finite complementation contrasts with infinitival complementation according to referentiality.

If complement clauses can have two values in that a. referential situations and b. non-referential situations can be embedded, the a.-value is mapped through the finite complement clause and the b.-value through the clause containing $z u$. Since both ways of expressing the referential status are exhausted, $1^{\text {st }}$ and $3^{\text {rd }}$ status are predicted not to occur in complement clauses, which is exactly the case:

$$
\begin{aligned}
& \text { a. } \quad \ldots * \text { dass ich dir befehle, stillstehen! } \\
& \text { b. } \quad \ldots * \text { dass ich dir befehle, stillgestanden! } \\
& \text { c. } \quad \ldots \text { dass ich dir befehle, stillzustehen! } \\
& \quad \ldots \text { that I order you to stand still' }
\end{aligned}
$$

Thus there are two possibilities to form complement clauses: finite, i.e., referential complement clauses and non-finite, i.e., non-referential complement clauses. 
With respect to referentiality, sentence mood, and complementation, the whole verbal paradigm is organized as follows.

(42) Referentiality, sentence mood, and complementation

\begin{tabular}{c|cc|c||c}
\multirow{2}{*}{} & \multicolumn{3}{|c||}{$\mathrm{V}_{\text {non-finite }}$} & \multirow{2}{*}{$\mathrm{V}_{\text {finite }}$} \\
\cline { 2 - 5 } & \multicolumn{1}{|c|}{ ST } & 3ST & $2 \mathrm{ST}$ & + \\
\hline referentiality & + & + & - & + \\
\hline sentence mood & + & + & - & +
\end{tabular}

\subsection{Left periphery}

To sum up, a clause containing $z u$ does not have a left periphery; dass and $z u$ have the same function within a clause, namely to make visible the highest head position. dass and $z u$ do not appear in the same context. But there is a set of data that seems to lead to a contradiction.

a. Er geht an die See, (um) sich zu erholen. (infinitival adjunct)

'He is going to the sea in order to recover.'

b. Er hat versucht, (*um) sich zu erholen.

(infinitival complement)

'He tried to recover.'

a. Er hat bedauert, dass er sie nicht gesehen hat.

(finite complement)

'He regretted that he did not see her.'

b. Er hat bedauert, sie nicht gesehen zu haben.

(infinitival complement)

'He regretted not to have seen her.'

Actually, it appears that um occurs in the left periphery, but never introduces a complement but a adjunct. Thus the distribution and properties of elements summarized in (2) of section 1 above does not have to be stated but can be made to follow completely from our discussion. 
(45) Distribution of items and properties

\begin{tabular}{c|c|c|c|c} 
& & complementizer & $\begin{array}{c}\text { prospective } \\
\text { marker }\end{array}$ & $\begin{array}{c}\text { functional } \\
\text { extension }\end{array}$ \\
\cline { 2 - 5 } Complement & finite & + & - & + \\
\cline { 2 - 5 } & $\begin{array}{c}\text { non- } \\
\text { finite }\end{array}$ & - & + & - \\
\hline Adjunct & $\begin{array}{c}\text { non- } \\
\text { finite }\end{array}$ & + & + & -
\end{tabular}

Rizzi (1997) is right with his assumption that the distribution of elements in the left periphery in subordinated clauses expresses external properties of the matrix verb as well as internal properties of the projecting head. We can observe that neither the inward quality (projecting verbal head) nor the outward quality (matrix verb) exclusively account for the conformation of a sentence.

\section{Conclusions}

Since types of sentence mood can vary in relation to referentiality while referentiality always remains constant with respect to different derivational levels, I will view referentiality as the more general property of sentences. Accordingly, the different types of sentence mood can be considered a derivation of a more general property of sentences.

If a German sentence functions as a syntactic complement, it has to be marked as such in a position left of and adjacent to the head of its highest projection. While finite clauses are a projection of the functional extension of the verbal head, non-finite clauses do not have a functional extension. Accordingly, the position for the marking of the complement status of a clause depends on whether the clause is finite or not: The complement status of a finite clause is marked on its left periphery by subordinating conjunctions such as dass and $o b$, while the complement status of a non-finite clause is marked left-adjacent to the verbal stem by the aspectual marker $z u$. As markers of the complement status of a clause, the complementizers dass and $o b$ and the aspectual marker $z u$ are functionally equivalent. Whether a sentence is finite or not was argued to be a consequence of its referential status: all and only referential clauses are functionally extended. While dass marks that its clause is referential, $z u$ marks that it is not. 


\section{Notes}

1. In the first place I would like to thank the editors Susanne Trissler and Horst Lohnstein for extended discussion and patience during the coming out of this volume as well as for their agreeable conducting guidance of the LeftPeriphery Workshop. I am grateful for the professional and personal environment at the University of Cologne. For their encouragement I would like to thank Beatrice Primus, Jürgen Lenerz and Werner Abraham. For the numerous discussions that inspired me to many substance and conceptual considerations, I thank Robert Kemp. Furthermore, I have learned a lot from the discussions with Kay González, Claudia Maienborn and the participants of the linguistic working group at the University of Cologne. Among those who helped directly are Jessica Schwamb and Moritz Neugebauer. For all remaining errors I am responsible.

2. For an investigation of the phenomena of multiple filled $\mathrm{C}$ and the fine structure of the left periphery, see Bayer (this volume).

3. In contrast to German, Dutch does not seem to show such a contrast. The appearance of the complementizer is optional: Hij probeert (om) te roken.

4. In general, non-finite complement clauses occur without complementizer except for "two-place" complementizers such as nicht nur ... sondern auch, see a. and $b$.

a. Er verspricht, nicht nur/weder einzukaufen, sondern auch/noch zu kochen.

'He promises not only / neither to shop but also/nor to cook.'

b. Er verweigert, sowohl zu essen als auch zu trinken

'He refuses both to eat and to drink'

5. The complements of verbs such as scheinen and pflegen do not have sentential properties. The $z u$-marked non-finite verb and matrix verb form an obligatory coherent construction in the middle field. But only $z u$-marked infinitives can be extraposed and have sentential properties, see *dass sie sehen, uns kommen.

6. The so called $3^{\text {rd }}$ construction shows evidence for coherence in complete extraposition, see Wöllstein-Leisten (2001).

7. Functional extension of the lexical category $V:(\mathrm{V} / \mathrm{VP} \rightarrow \mathrm{I} / \mathrm{IP} \rightarrow \mathrm{C} / \mathrm{CP})$

8. Höhle 1991 discusses constructions with non-detachable prefix verbs like urauffïhren 'to première', zwischenfinanzieren 'to finance temporarily', rückfragen 'to ask again'.

9. $\mathrm{F}^{0}$ labels the functionally specified highest head position.

10. The participium is not governed, i.e., it is not a complement, neither a sentential nor a verbal one.

11. The phenomena of empty head position in $\mathrm{CP}$ in subordinated w-phrases is discussed in Bayer, section 8.1.1 (this volume). 
12. The formation of a verbal complex is not a neccessary condition for a coherent construction, see Wöllstein-Leisten (2001) for the third construction.

13. Compare the following examples with the auxiliary and the $1^{\text {st }}$ or $2^{\text {nd }}$ status:, dass Maria hat (Aux) kommen müssen ( $1^{\text {st }}$ status), dass Maria zu kommen ( $2^{\text {nd }}$ status) hat (Aux).

14. She does not decompose the non-finite paradigm with respect to aspectuality.

15. Also the category $\mathrm{N}$ refers to a possible object with a shape of spread or dimensions, see Wunderlich (1993:65).

16. Can also be indicated as imperfective or progressive.

17. Bartsch (1995:128) offers the following characterization for aspect: [Aspects] ...They respectively characterize anteriority, interiority or posteriority with respect to the situations denoted by the verb. This corresponds to the distinction by Lohnstein/Wöllstein-Leisten of perfective, durative, and prospective aspect.

18. Under the assumption of blocking and deblocking of arguments by lexical items such as auxiliaries or verbal status, Haider (1984) makes the following generalizations: The $2^{\text {nd }}$ status is an unselective blocking element for the external argument; the auxiliary haben 'have' is an unselective deblocking element. The choice of the type of auxiliary corresponds to the type of argument: the auxiliary sein 'be' correlates with the presence of an external (not designated) argument, with the exception of deblocking contexts with ergative verbs, see Die Blume hat zu erblühen. , 'The flower has to bloom.'

19. This interpretation as preceeding state is held up in both constructions where an auxiliary yields a modal reading, thus: The computer has/is to be repaired.

20. For detailed discussion see Maienborn (2001).

21. Similarly, there are good reasons to assume that $D$ is the extension of the category $N$, see Wunderlich (1993:54).

22. The conventional classification $N[+\mathrm{N}-\mathrm{V}]$ and $V[-\mathrm{V}+\mathrm{N}]$ does not reflect the similarities of the lexical categories $N$ and $V$.

23. It is meant that arguments must be phonologically represented.

24. $V$ (like the main category $\mathrm{N}$, as opposed to the minor categories $\mathrm{A}$ and $\mathrm{P}$ ) possesses a referential argument.

25. For a detailed debate see Lohnstein (2000:41).

26. Beatrice Primus has directed my attention to this correlation.

27. In the sense of being the case by now.

28. It is not the presence but the absence of a marker, that is $-t$ in the $1^{\text {st }}$ and the $2^{\text {nd }}$ status which is relevant.

29. It might be a very interesting question, why we recycle (recycling idea from Robert Kemp) exactly the finite plural markers as infinitival marker. The right-peripheral infinitival marker just like the finite plural marker do have the property to refer to more than one concrete object. Perhaps that is what is needed for infinitival marking. 
30. In Bredel/Lohnstein (2001), $[+\mathrm{t}]$ indicates a feature of the deictic system in the sense of being far from the origo. Underspecification of the [t]-feature $([\alpha t])$ allows both markers $e n / t$ to appear.

31. At this point in time it is not yet clear whether the degree of abstractness suffices to transfer this concept to the categories $N / D$. In this case, we could observe similarities in the nominal domain with the concept of referentiality beyond the verbal domain. I suggest that on this level we are dealing with the same sort of features. If referentiality were the more general concept, we could assume $N / V$ [+ref/-ref] instead of $N$ [+def/-def] and $V$ [+fin/-fin] for the referential syntagmas $N$ and $V$.

32. Note that there are several restrictions as for clauses with request character in general: they cannot be embedded, but form matrix clauses.

33. It seems that in Austrian the following is possible: Bitte sich nicht hinaus zu lehnen. 'Please, do not lean out.' (Susanne Trissler drew my attention to this data.)

34. Some scholars may argue that in the left periphery the distinction between coherent and incoherent constructions gets lost because the projection level is no longer responsible for the distinction between these construction types. In this respect they are absolutely right. It has also been argued that coherence and incoherence is a property of the selecting verb and not of the selected one. With this I also agree. Consequently, we then could not argue for a structural analysis of the data any more. To this objection I reply the following: It should be remembered that the greater riddle - the phenomenon of coherence itself - is not yet understood. Moreover, we are not yet aware of all the abstract property those verbs share that are able to take part in coherent constructions or obligatorily take part in incoherent constructions, respectively. For a subclass of verbs of the latter type - factive verbs (e.g., bedauern, leugnen, zugeben, etc.) - Heilmann / Wöllstein-Leisten (1997) have demonstrated that there are in fact abstract properties.

35. Notice that the $3^{\text {rd }}$ status is not possible: $*$ Womit noch gerechnet. The $1^{\text {st }}$ status under negation leads to an echo-interpretation: Womit nicht rechnen können?

36. For a discussion of the illocutionary force of independent finite V-final clauses, unembedded bare infinitives, and perfective participials see Bayer, section 9.3.2 (in this volume).

37. See also Reis (2002). 


\section{References}

Bartsch, Renate

1995 Situations, Tense and Aspect. Berlin, New York: de Gruyter.

Bech, Gunnar

1983 Studien über das deutsche verbum infinitum. $2^{\text {nd }}$ ed. Tübingen:

Niemeyer. Original edition, 1955/57.

Brandt, Margareta, Marga Reis, Inger Rosengren, and Ilse Zimmermann,

1992 Satztyp, Satzmodus und Illokution. In Satz und Illokution, Inger

Rosengren (ed.), 1-90. Tübingen: Niemeyer

Bredel, Ursula and Horst Lohnstein

2001 Zur Ableitung von Tempus und Modus in der deutschen Verbal-

Davidson, Donald

flexion. Zeitschrift für Sprachwissenschaft 20 (2): 218-250.

2001 The logical form of action sentences. In Essays on Actions and

Events, Donald Davidson (ed.), 105-122. Oxford: Clarendon

Press. Original edition, 1967.

Evers, Arnold

1975 The Distributional Cycle in German and Dutch. Reproduced by IULC, Bloomington.

Grewendorf, Günther

1987 Kohärenz und Restrukturierung: Zu verbalen Komplexen im Deutschen. In Neuere Forschungen zur Wortbildung und Historiographie der Linguistik, Brigitte Asbach-Schnittker, and JoGrimshaw, Jane hannes Roggenhofer (eds.), 123-144. Tübingen: Narr.

1991 Extended Projections. Ms., University of Brandeis.

Haider, Hubert

1984 Was zu haben ist und was zu sein hat. Bemerkungen zum Infinitiv. Papiere zur Linguistik 30: 23-36.

1987 Nicht-sententiale Infinitive. Groninger Arbeiten zur germanistischen Linguistik 28: 73-114.

1993 Deutsche Syntax - generativ. Vorstudien zur Theorie einer projektiven Grammatik. Tübingen: Narr.

Heilmann, Axel, and Angelika Wöllstein-Leisten

1997 The Syntax-Semantic Interface: Conditions for infinitival complementation. Arbeitspapiere des SFB 340, No. 104. University of Stuttgart, University of Tübingen

Higginbotham, James

2000 On events in linguistic semantics. In Speaking of Events, James Higginbotham, Fabio Pianesi, and Achille Varzi (eds.), 49-79. New York, Oxford: Oxford University Press. 
Höhle, Tilman

1997 Vorangestellte Verben und Komplementierer sind eine natürliche Klasse. In Sprache im Fokus. Festschrift für Heinz Vater zum 65. Geburtstag, Christa Dürscheid, Karl-Heinz Ramers, and Monika Schwartz (eds.), 107-120. Tübingen: Niemeyer.

1991 Projektionsstufen bei V-Projektionen. Ms., University of Tübingen.

Jacobs, Joachim

1990 Skopus und Inkohärenz. Ms., University of Wuppertal.

Klein, Wolfgang

2000 An analysis of German perfect. Language 76: 358-382.

Lohnstein, Horst

2000 Satzmodus - kompositionell. Zur Parametrisierung der Modusphrase im Deutschen. Berlin: Akademie Verlag.

Lohnstein, Horst, and Angelika Wöllstein-Leisten.

2001 Status als Aspektmarker. Ms., University of Cologne.

Maienborn, Claudia

2001 Die logische Form von Kopulasätzen. Habilitationsschrift. Humboldt Universität zu Berlin.

Parsons, Terence

2000 Underlying states and time travel. In Speaking of Events, James Higginbotham, Fabio Pianesi, and Achille Varzi (eds.), 81-93. New York, Oxford: Oxford University Press.

Reis, Marga

2002 On Wh-infinitivals in German. Ms., University of Tübingen.

Rizzi, Luigi

1997 The fine structure of the left periphery. In Elements of Grammar, Liliane Haegemann (ed.), 281-337. Dordrecht: Kluwer.

Rosengren, Inger

1992 Zum Problem der kohärenten Verben im Deutschen. In Biologische und soziale Grundlagen der Sprachfähigkeit, Peter Suchsland (ed.), 265-297. (Akten des 3. Jenaer Symposiums) Tübin-

Sabel, Joachim gen: Niemeyer.

1996 Restrukturierung und Lokalität. Berlin: Akademie Verlag.

Stechow, Arnim von, and Wolfgang Sternefeld.

1988 Bausteine syntaktischen Wissens. Opladen: Westdeutscher Verlag.

Steinitz, Renate

1997

Lexikalische Kategorisierung: Ein Vorschlag zur Revision. In Lexikalische Kategorien und Merkmale, Elisabeth Löbel, and Gisa Rauh (eds.), 1-26. Tübingen: Niemeyer. 
Wöllstein-Leisten, Angelika

2001 Die Syntax der dritten Konstruktion. Tübingen: Stauffenburg.

Wunderlich, Dieter

1996 Lexical categories. Theoretical Linguistics 22: 2-48.

1993 Funktionale Kategorien im Lexikon. In Theorie und Praxis des Lexikons, Frank Beckmann, and Gerhard Heyer (eds.), 54-73.

Berlin: de Gruyter.

Wurmbrandt, Susanne

2001 Infinitives. Restructuring and Clause Structure. Berlin, New York: Mouton de Gruyter. 